\title{
Communication
}

[Comunicação]

\section{Study on prevalence and liver function test enzymes of differently plumaged peafowls (Pavo cristatus) infected with Toxoplasma gondii in captivity}

\author{
[Estudo sobre enzimas de prevalência e teste da função hepatica de pavões de plumage diferente (Pavo cristatus) \\ infectados com Toxoplasma gondii em cativeiro] \\ M.H. Lashari ${ }^{1}$, H. Anjum ${ }^{2}$, W Hassan ${ }^{3}$, S. Mubeen ${ }^{4}$, M.F. Azhar ${ }^{5}$, U. Farooq ${ }^{6}$, M. Anam ${ }^{1}$, \\ N. Sial ${ }^{1}$, A.B. Gulshan ${ }^{7}$, M. Nawaz ${ }^{8}$, S. Masood ${ }^{9}$, M. Naeem ${ }^{9}$, M.I. Khan ${ }^{10^{*}}$ \\ ${ }^{1}$ Department of Zoology, The Islamia University of Bahawalpur - Bahawalpur Pakistan \\ ${ }^{2}$ Department of Zoology, Virtual University of Pakistan \\ ${ }^{3}$ Department of Chemistry, The Women University - Multan Pakistan \\ ${ }^{4}$ Sub-Campus Toba-Tek Singh, University of Agriculture - Faisalabad Pakistan \\ ${ }^{5}$ Department of Forestry and Range Management B. Z. University - Multan Pakistan \\ ${ }^{6}$ University College of Veterinary and Animal Sciences, The Islamia University of Bahawalpur -Bahawalpur, Pakistan \\ ${ }^{7}$ Department of Botany. Ghazi University - D.G. Khan, Pakistan \\ ${ }^{8}$ Department of Environmental Sciences, B.Z. University - Multan, Pakistan \\ ${ }^{9}$ Institute of Pure \& Applied Biology - B.Z. University - Multan, Pakistan \\ ${ }^{10}$ School of Energy and Power Engineering, Xi'an Jiaotong University, 28 West Xianning Road, Xi'an 710049, \\ Shaanxi, PR. China
}

The birds in captivity in Pakistan and elsewhere face many infectious disease problems such as toxoplasmosis caused by Toxoplasma gondii ( $T$. gondii). The $T$. gondii is an obligate intracellular parasite which causes toxoplasmosis in birds and mammalia (Tenter et al., 2000). Felids or cats are its definitive hosts while birds and mammals are intermediate hosts (Dubey et al., 2010). Cats shed oocysts in their stool that contaminate the environment and remain infective for more than one year, which permits the transmission of infection to intermediate hosts like birds, mammals, sheep, goats and humans.

In birds, seroprevalence of $T$. gondii is best indicator to access the soil contamination with sporulated oocytes. In birds, it causes loss of appetite, yellowing of mucous, maceration, diarrhea and abnormal functioning of the central nervous system. Like other birds, peafowl is also an intermediate host of Toxoplasma gondii. The infection rate of Toxoplasma gondii varies by country.

Recebido em 21 de setembro de 2019

Aceito em 22 de junho de 2020

Autor para correspondência (corresponding author)

*E-mail: mushtaqlashary@gmail.com; raoimranishaq@gmail.com
Studies on toxoplasmosis in peafowl are limited in Pakistan. Similarly, hematological and biochemical parameters show the health and metabolic status of the body, but no information is available about biochemical parameters altered due to the infestation of $T$. gondii in captive peafowls. Considering the role of birds in infection of Toxoplasma gondii to humans and also according to our knowledge, there is no documented report about the prevalence of toxoplasmosis in captive birds in Pakistan. Therefore, the present survey was conducted to examine the effect of toxoplasmosis in peafowl in captivity and its effects on serum activity of liver enzymes of both seropositive and seronegative peafowls.

The present study was conducted in in Bahawalpur Zoo, Bahawalpur, Pakistan from January to August 2018. The zoo was established in 1942 and is the fourth biggest zoo of Pakistan. Its total area is 25 Acres donated by Sir Nawab Sadiq Muhammad Khan Abbasi, the former 'Amir of Bahawalpur'. It houses about 870 animals including a number of primates, big cats, 
deer, antelope, ratites, reptiles and birds. It lies from $29.402764^{\circ} \mathrm{N}$ to $71.681601 \mathrm{E}^{\circ}$ and $112 \mathrm{~m}$ above the sea level where the average rainfall is 20 to $25 \mathrm{~cm}$ annually. The Animal Ethics Committee of the Islamia University of Bahawalpur (IUB), Pakistan approved this study.

Blood samples were collected from the peafowls $(\mathrm{n}=100) \quad(45$ male and 55 females) from differently plumaged peafowls including blue $(\mathrm{n}=28)$, white $(\mathrm{n}=10)$, pied $(\mathrm{n}=10)$ and black shoulder $(n=52)$. Information about age, sex and physical condition of birds was gathered during blood sampling. Age-wise peafowls were divided into two groups viz. adults (24-36 months) and young (7-9 months). The blood samples were allowed to clot for nearly one hour and then subjected to centrifuge for $15 \mathrm{~min}$. Serum was harvested and kept at $-20^{\circ} \mathrm{C}$ until further analyzed for serum chemistry attributes at the Parasitology Research Laboratory of Department of Zoology, IUB.

The commercially available Toxo Latex Kit (Atlas Medical, Blankenfelde, Germany) was used to detect specific antibodies in serum of birds that consisted of a positive control, a negative control and a Latex Reagent. The reagent contained suspension of polystyrene particles coated with antigen of $T$. gondii. Positive control shows agglutination when added to serum and negative control does not show agglutination. Antigen- antibody reaction could take place when serums which contain antibodies against $T$. gondii were tested and this reaction can be easily visualized because of agglutination. Both the reagents and serum were brought at the room temperature prior to use. A serum sample of bird was serially diluted twofold in phosphate buffered saline from $1: 2$ to $1: 8$.

A sample found positive at $1: 2$ to $1: 8$ serial dilutions was tested at higher, doubling dilutions $1: 16,1: 32,1: 64$. One drop of diluted serum sample was placed onto the black area of the slide. The latex reagent was mixed well, and one drop was added to each serum drop. Both drops were mixed with the help of a stirrer and the slide was tilted. A clear positive reaction indicated the presence of $T$. gondii antibodies, which reflected either a past infection or an evolving infection. A negative reaction indicated the absence of $T$. gondii antibodies.

The Toxoplasma IgM ELISA kit (Calbiotech Inc. CA, USA) was used to examine $T$. gondii antibodies in birds as per manufacturer's instructions. Serum samples, positive and negative controls were added to the microwells. $T$. gondii antibodies if present in serum samples showed agglutination by forming an antibodyantigen complex. All unbound antibodies were washed away, and enzyme conjugate was added which bind to the antibody-antigen complex. Excess enzyme conjugate was washed away and the substrate (TMB) was added. The plate was allowed to incubate, and the color was developed. A blue solution appeared in the presence of antibodies, which turned yellow after the addition of the stop solution. There was no coloration in the absence of antibodies. The development of color was stopped by adding stop solution. The optical density (OD) of the microplate was read at $450 \mathrm{~nm}$ with microplate absorbance reader 800 TS, BIOTK, UK. Results were written as the $\%$ age of the mean absorbance values of the sample (S) to the mean absorbance value of positive (P) control given with the diagnostic kit. According to manufacturer's reference, sera with $\mathrm{S} / \mathrm{P} \leq 40 \%=$ Negative, $40 \%>50 \%$ Doubtful, $50 \% \leq \mathrm{S} / \mathrm{P}<$ $200 \%=$ Positive, $\mathrm{S} / \mathrm{P} \geq 200 \%=$ Strong positive.

Liver function test enzymes such as Albumin, bilirubin, Alanine aminotransferase (ALT), Aspartate aminotransferase (AST) and Alkaline phosphatase (ALP) were analyzed using commercial assay kits (Spinreact, Spain) and a chemistry analyzer. The data were subjected to Chi-square statistical analysis using the minITAB version 16.0 software. Results were tested against $\mathrm{P} \leq 0.05$ for significance. According to LAT, $37 \%$ (37/100) of peafowls were found to be positive. The overall prevalence in the pied, blue, black shoulder and white plumage peafowl was (4/10) $40 \%$, (11/28) 39.28\%, (19/52) $36.58 \%$ and (3/10) $30 \%$, respectively. Gender-wise non-significantly higher prevalence was recorded in males $(17 / 45)$ $37.77 \%$ as compared to females (20/55) $36.36 \%$. Similarly, non-significantly higher prevalence (30/79) $37.97 \%$ was recorded in adults as compared to young ones (7/21) $33.33 \%$ (Table 1). 
Study on prevalence...

Table 1. The prevalence of Toxoplasma gondii in peafowl by LAT and ELISA

\begin{tabular}{|c|c|c|c|c|c|c|c|}
\hline Groups & Category & $\begin{array}{l}\text { By LAT } \\
\text { Peafowls } \\
\text { examined } \\
(n=100)\end{array}$ & $\begin{array}{l}\text { Infected } \\
\text { Peafowls }\end{array}$ & $\begin{array}{c}\text { Prevalence } \\
\%\end{array}$ & $\begin{array}{c}\text { Peafowls } \\
\text { examined } \\
(n=100)\end{array}$ & $\begin{array}{l}\text { By ELIS } \\
\text { Infected } \\
\text { Peafowls }\end{array}$ & $\begin{array}{c}\text { Prevalence } \\
\%\end{array}$ \\
\hline Plumage & $\begin{array}{l}\text { Pied } \\
\text { Blue } \\
\text { Black } \\
\text { shoulder } \\
\text { White }\end{array}$ & $\begin{array}{l}10 \\
28 \\
52 \\
10\end{array}$ & $\begin{array}{c}4 \\
11 \\
19 \\
3\end{array}$ & $\begin{array}{c}40^{\mathrm{a}} \\
39.28^{\mathrm{b}} \\
36.58^{\mathrm{b}} \\
30^{\mathrm{b}}\end{array}$ & $\begin{array}{l}10 \\
28 \\
52 \\
10\end{array}$ & $\begin{array}{c}2 \\
8 \\
17 \\
3\end{array}$ & $\begin{array}{c}20^{\mathrm{a}} \\
28.57^{\mathrm{a}} \\
32.69^{\mathrm{b}} \\
30^{\mathrm{b}}\end{array}$ \\
\hline Gender & $\begin{array}{l}\text { Male } \\
\text { Female }\end{array}$ & $\begin{array}{l}45 \\
55\end{array}$ & $\begin{array}{l}17 \\
20\end{array}$ & $\begin{array}{l}37.77^{\mathrm{a}} \\
36.36^{\mathrm{a}}\end{array}$ & $\begin{array}{l}45 \\
55\end{array}$ & $\begin{array}{l}16 \\
14\end{array}$ & $\begin{array}{l}35.55^{\mathrm{a}} \\
25.45^{\mathrm{b}}\end{array}$ \\
\hline Age & $\begin{array}{l}\text { Young } \\
\text { Adult }\end{array}$ & $\begin{array}{l}21 \\
79\end{array}$ & $\begin{array}{c}7 \\
30\end{array}$ & $\begin{array}{l}33.33^{\mathrm{a}} \\
37.97^{\mathrm{a}}\end{array}$ & $\begin{array}{l}21 \\
79\end{array}$ & $\begin{array}{c}5 \\
25\end{array}$ & $\begin{array}{l}23.80^{\mathrm{a}} \\
31.64^{\mathrm{b}}\end{array}$ \\
\hline
\end{tabular}

In columns different superscripts show significant difference $(\mathrm{P}<0.05)$.

According to ELISA, the overall prevalence was $30 \%(30 / 100)$ and in different plumages such as pied, blue, black shoulder and white plumage peafowls, it was $(2 / 10) 20 \%$, (8/28) $28.57 \%$, (17/52) $32.69 \%$ and (3/10)30\%, respectively. Gender-wise, significantly higher prevalence was observed in males (16/45) $35.55 \%$ as compared to females (14/55) $25.45 \%$. Age-wise, significantly higher (25/79) $31.64 \%$ infestation was recorded in adults as compared to young birds (5/21) $23.80 \%$ (Table 1). Level of bilirubin was non-significant, while the level of Albumin and ALP were significantly elevated in infected than in noninfected hosts. The ALT and AST decreased in the infected hosts than in non-infected peafowls (Table 2).

Table 2. Mean \pm SEM values of liver function test enzymes in infected and non- infected hosts

\begin{tabular}{|c|c|c|c|c|c|c|c|c|}
\hline Parameters & & infecte & hosts & & & Non-infe & ted hosts & \\
\hline $\begin{array}{l}\text { Liver } \\
\text { function } \\
\text { tests }\end{array}$ & $\begin{array}{l}\text { Black } \\
\text { shoulder } \\
\text { plumage }\end{array}$ & $\begin{array}{l}\text { White } \\
\text { plumage }\end{array}$ & $\begin{array}{l}\text { Blue } \\
\text { plumage }\end{array}$ & $\begin{array}{l}\text { Pied } \\
\text { plumage }\end{array}$ & $\begin{array}{l}\text { Black } \\
\text { shoulder } \\
\text { plumage }\end{array}$ & $\begin{array}{l}\text { White } \\
\text { plumage }\end{array}$ & $\begin{array}{l}\text { Blue } \\
\text { plumage }\end{array}$ & $\begin{array}{l}\text { Pied } \\
\text { plumage }\end{array}$ \\
\hline Bilirubin & $\begin{array}{l}1.7 \pm \\
0.10^{\mathrm{a}}\end{array}$ & $\begin{array}{l}1.56 \pm \\
0.41^{\mathrm{a}}\end{array}$ & $\begin{array}{l}1.92 \pm \\
0.20^{\mathrm{a}}\end{array}$ & $\begin{array}{l}1.45 \pm \\
0.25^{\mathrm{a}}\end{array}$ & $\begin{array}{l}1.71 \pm \\
0.06^{\mathrm{a}}\end{array}$ & $\begin{array}{l}1.47 \pm \\
0.08^{\mathrm{a}}\end{array}$ & $\begin{array}{l}1.72 \pm \\
0.40^{\mathrm{a}}\end{array}$ & $\begin{array}{l}1.46 \pm \\
0.51^{\mathrm{a}}\end{array}$ \\
\hline Albumin & $\begin{array}{l}3.28 \pm \\
0.18^{\mathrm{a}}\end{array}$ & $\begin{array}{r}3.65 \pm \\
0.46^{\mathrm{a}}\end{array}$ & $\begin{array}{l}3.22 \pm \\
0.33^{\mathrm{a}}\end{array}$ & $\begin{array}{l}2.81 \pm \\
0.51^{\mathrm{a}}\end{array}$ & $\begin{array}{l}3.49 \pm \\
0.15\end{array}$ & $\begin{array}{l}2.84 \pm \\
0.19^{\mathrm{b}}\end{array}$ & $\begin{array}{l}3.22 \pm \\
0.76^{\mathrm{a}}\end{array}$ & $\begin{array}{l}3.09 \pm \\
0.29^{b}\end{array}$ \\
\hline ALT & $\begin{array}{l}58.53 \pm \\
3.17^{\mathrm{a}}\end{array}$ & $\begin{array}{l}41.66 \pm \\
0.33^{\mathrm{a}}\end{array}$ & $\begin{array}{l}61.63 \pm \\
4.23^{\mathrm{a}}\end{array}$ & $\begin{array}{l}64.5 \pm \\
1.50^{\mathrm{a}}\end{array}$ & $\begin{array}{l}62.71 \pm \\
1.67\end{array}$ & $\begin{array}{l}62.86 \pm \\
2.44^{b}\end{array}$ & $\begin{array}{l}58.40 \pm \\
11.27^{\mathrm{b}}\end{array}$ & $\begin{array}{l}54.13 \pm \\
3.38^{b}\end{array}$ \\
\hline AST & $\begin{array}{l}68.53 \pm \\
3.16^{\mathrm{a}}\end{array}$ & $\begin{array}{l}73.33 \pm \\
8.35^{\mathrm{a}}\end{array}$ & $\begin{array}{l}68.50 \pm \\
5.99^{\mathrm{a}}\end{array}$ & $\begin{array}{l}76.5 \pm \\
10.51^{\mathrm{a}}\end{array}$ & $\begin{array}{l}75.37 \pm \\
2.04\end{array}$ & $\begin{array}{l}66.57 \pm \\
7.12^{\mathrm{b}}\end{array}$ & $\begin{array}{l}75.70 \pm \\
11.35^{\mathrm{b}}\end{array}$ & $\begin{array}{l}68.8 \pm \\
8.40^{\mathrm{b}}\end{array}$ \\
\hline ALP & $\begin{array}{l}520.3 \pm \\
66.41^{\mathrm{a}}\end{array}$ & $\begin{array}{l}283.3 \pm \\
21.90^{\mathrm{a}}\end{array}$ & $\begin{array}{l}584.1 \pm \\
91.81^{\mathrm{a}} \\
\end{array}$ & $\begin{array}{l}893 \pm \\
0.50^{\mathrm{a}}\end{array}$ & $\begin{array}{l}463.6 \pm \\
38.11^{\mathrm{b}}\end{array}$ & $\begin{array}{l}476.0 \pm \\
114 .{ }^{b}\end{array}$ & $\begin{array}{l}478.2 \pm \\
239.2^{b}\end{array}$ & $\begin{array}{l}298 \pm \\
31.32^{b}\end{array}$ \\
\hline
\end{tabular}

In rows different superscripts show significant difference $(\mathrm{P}<0.05)$.

In Pakistan, no data is available on seroprevalence of $T$. gondii in peafowls. This is the first such study on seroprevalence of peafowls kept at Bahawalpur Zoo, Pakistan. Among birds, peafowls also serve as intermediate hosts which cause significant health problems to the public
(Tian et al., 2012). The results attained through LAT were re-tested by ELISA in order to enhance diagnostic accuracy in the present study. Previous researches have reported a higher seroprevalence of $T$. gondii in birds in different regions of the world including Iran (32.3\%), China (31.8\%), and 
Iraq $(31 \%, 67 \%$ and $56 \%)$ in geese, peafowls, ducks and chicken, respectively (Tian et al., 2012, Lashari et al., 2018). Lower prevalence rate has been recorded in Colorado (3.9\%), Portugal (4.6\%), and China (8.36\%) by Dubey et al., 2010, Waap et al., 2008 and Zhang et al., 2014 for pigeons, parrots and pet birds, respectively. The difference in prevalence could be attributed to difference in breed and species of birds.

In the present study, according to LAT and ELISA, a higher prevalence rate was recorded in males as compared to females. Zhang et al. (2104) in China reported higher prevalence of $T$. gondii in male $(10.43 \%)$ parrots as compare to females $(6.08 \%)$. Same results have been reported by Lashari et al. (2018). The relation of gender with susceptibility of host to toxoplasmosis might be due to genetic predisposition and difference in hormones. Testosterone is known for its immunosuppressive activity (Seli and Arici, 2002). The females can be immune because of different factors e.g. diet, age and surrounding conditions. Males are less susceptible to protozoan parasites than females. Causes of higher prevalence of $T$. gondii antibodies in males in present study may be due to steroid hormonal difference.

In the present study, a significant difference $(\mathrm{P}<0.05)$ was detected in seropositive adult hosts as compared to young hosts. Similar results have been reported by Zhang et al. (2104). Present and previous studies showed that adults have more chance to get an infection by ingestion of oocysts with contaminated food because they have a wide range of feeding area than young ones.

The present study showed significant biochemical changes with statistically high level of bilirubin, Albumin and ALP in the infected host as compared to non-infected hosts. ALT increased in infected blue and pied plumaged peafowls whereas level of AST elevated in infected white and pied plumaged peafowls. In general, the analysis revealed that there was a significant effect of toxoplasmosis on liver function test enzymes of hosts. Similar results were reported by Amany et al. (2010) from Egypt, Dawood and Mahmood (2012). In contrast to the current study, a decreased level of albumin and elevated level of ALT and AST have also been recorded in $T$. gondii infected hosts (Amany et al., 2010). In serum, biochemical profile level of AST and ALT indicate the working condition of liver cells.

These enzymes play a significant role in metabolic transmission of amino acid mostly present in the liver and some other tissues. In case of any cellular damage, AST and ALT spread into the surrounding tissues and its level of activity increased. In case of any hepatic injury activity level of AST and ALT increases (Adeyemi and Akanji, 2011). Toxoplasmosis causes infiltration of liver cells and in portal area, damage endothelial cells and necrosis in hepatocytes. Moreover, the elevated level of AST and ALT also provide information about infection and inflammation induced by $T$. gondii. Toxoplasmosis causes significant and permanent destruction to the liver, noteworthy developments of organisms arising in alterations in the metabolism of the liver (Amany et al., 2010).

In a nutshell, toxoplasmosis is widespread in peafowls in Bahawalpur Zoo, Pakistan which indicates an environmental contamination with oocysts of $T$. gondii. According to LAT and ELISA highest prevalence was recorded in males as compared to females. Age-wise higher prevalence was recorded in adult peafowls. Toxoplasmosis also affects the liver function test enzymes of the hosts. The present study may provide preliminary data for the control of $T$. gondii in other zoo birds to minimize the load of $T$. gondii. We recommend the zookeepers, veterinary staff and allied stake holders to devise a directional strategy towards control and eradication of $T$. gondii.

\section{RESUMO}

O presente estudo foi realizado para determinar a prevalência geral de toxoplasmose em pavões de plumagem diferente e seu efeito nas enzimas de teste da função hepática dos hospedeiros. Um total de cem pavões de plumas diferenciais, como ombro preto $(n=52)$, azul $(n=28)$, branco $(n=10)$ e arlequim $(n=$ 10) foram estudados no zoológico de Bahawalpur, no Paquistão, usando o Latex Agglutination Test (LAT) e ensaio imunossorvente ligado a enzima (ELISA). A prevalência geral por LAT e ELISA foi de 37\% e 30\%, respectivamente. Por $L A T$, observou-se uma prevalência não significativamente maior $(P \geq 0,05)$ em gênero 
(37,77\%) nos machos do que nas fêmeas (36,36\%), enquanto os adultos apresentaram uma prevalência maior (37,97\%) em relação aos jovens (33,33\%). De acordo com o ELISA, uma prevalência significativamente $(P<0,05)$ maior $(35,55 \%)$ foi observada nos machos do que nas fêmeas $(25,45 \%) e$ significativamente $(P<0,05)$ maior prevalência $(31,64 \%)$ foi registrada nos adultos do que nos jovens (23,80\%). A análise do perfil bioquímico sérico mostrou que o nível de bilirrubina não teve elevação significativa nos hospedeiros infectados, em comparação aos não infectados, enquanto a concentração de albumina, alanina aminotransferase (ALT), aspartato aminotransferase (AST), fosfatase alcalina (ALP) foi significativamente $(P<0,05)$ diferente nos hospedeiros infectados. Conclui-se que a toxoplasmose afeta as enzimas do teste da função hepática. Essa é uma pesquisa preliminar e requer mais pesquisas em todo o país, com populações e amostras maiores.

Palavras-chave: Toxoplasmose, pavões, LAT, ELISA, enzimas de teste da função hepática

\section{REFERENCES}

ADEYEMI, O.S.; AKANJI, M.A. Biochemical changes in the kidney and liver of rats following administration of ethanolic extract of Psidium guajava leaves. Hum. Exp. Toxicol., v30, p.12661274, 2011.

AMANY, M.; EID, R.A.A.; FAHMY, B.G.A. Biochemical studies on the effect of Toxoplasma infection on liver and kidney functions in mice. Egypt. J. Com. Path. Clin. Path., v.23, p.174-185, 2010.

DAWOOD, M.N.; MAHMOOD, N.A. Liver function tests in toxoplasmosis. Ann. Coll. Med. Mosul, v38, p.68-72, 2012.

DUBEY, J.P.; FELIX, T.A.; KWOK, O.C.H. Serological and parasitological prevalence of Toxoplasma gondii in wild birds from Colorado. J. Parasitol., v.96, p.937-939, 2010.

LASHARI, M.H.; AFZAL, F.; FAROOQ, U. Hematological changes in free-range chicken (Gallus domesticus) naturally infected with Toxoplasma gondii. Sarhad J. Agric., v.34, p.973978, 2018.
SELI, E.; ARICI, A. Sex steroids and the immune system. Immunol. Allergy Clin. N. Am., v.22, p.407-408, 2002.

TENTER, A.M.; HECKEROTH, A.R.; WEISS, L.M. Toxoplasma gondii: from animals to humans. Int. J. Parasitol., v.30, p.1217-1258, 2000.

TIAN, Y.M.; DAI, F.Y.; HUANG, S.Y. et al. First report of Toxoplasma gondii seroprevalence in peafowls in Yunnan Province, Southwestern China. Parasit. Vectors, v.5, p.205, 2012.

WAAP, H.; VILARES, A.; REBELO, E. et al. Epidemiological and genetic characterization of Toxoplasma gondii in urban pigeons from the area of Lisbon (Portugal). Vet. Parasitol., v.157, p.306-309, 2008.

ZHANG, X.X.; ZHANG, N.Z.; TIAN, W.P. et al. First report of Toxoplasma gondii seroprevalence in pet parrots in China. Vector Borne Zoonotic Dis., v.14, p.394-398, 2014. 